\title{
原腊論文
}

\section{長期にわたる森林放置と植生変化が 年蒸発散量に及ぼす影響}

\author{
谷誠 1) 細田 育広 2) \\ 1) 京都大学農学研究科 \\ （开606-8502 京都市左京区北白川追分町） \\ 2) 森林総合研究所関西支所 \\ （テ612-0855＼cjkstart京都市伏見区桃山町永井久太郎68）
}

\begin{abstract}
岡山県にある竜ノ口山森林理水試験地の69年（1937～2005年）にわたるふたつの小流域の降水と流出のデー夕を 用いて, 森林放置と植生変化の年蒸発散量に及ぼす影響を評価した。毎年の水収支には貯留量が影響を及ぼすので, 年末の基底流出量がほぼ等しい期間を選び，その期間の損失を年平均蒸発散量とみなした。1947年以降植生が放置 されて広葉樹林が成長してきた流域では, 年蒸発散量は, 平均気温によって増減したが, 植生成長によって増加す る傾向や, 温暖化傾向のある1991〜2005年では, 蒸発散量の増加が拡大する傾向がみられた. 毎年の年損失量は, 森林の期間では, 年末の基底流出量と相関があったが, 森林未回復の期間では, 相関が涊められなかった。これは, 乾燥年でさえ蒸発散があまり抑制されずに持続する森林の特徴を示すものである．また，植生がクロマツ林であっ た期間は広葉樹林であった期間よりも年損失量が小さかったのであるが, 基潐流域との損失量の比較, 月流出量の 比較を行った結果, マツ林は広葉樹林よりも, 年蒸発散量, 冬季の遮断蒸発量, 夏季の蒸散量がともに大きいと推 定された.
\end{abstract}

キーワード : 年間水収支, 気候变動, 蒸発散, 森林水文学, 植生变化

\section{I 、はじめに}

里山は，農村の生活を支える燃料・肥料・建材な ど重要な資源を供給する場として数百年以上の長き に渡って利用されてきた。利用の程度や基岩地質に よって, コナラを主とする萌芽林, アカマツ天然林 が維持できたところもあれば，草山，はげ山になっ ていたところも多かった（千葉，1973；太田ら， 2009）。いずれの場合も，原生林のときに人間によっ て有機物が持ち出されることなく物質循環していた ときと比べて, 植生が貧弱にかつ土壤がやせてきた ための変化だと考えられる（徳地ら，2010）。そう した場合の流出特性の変化については, すでに報告 してきたところである (Tani et al., 2011). すなわち, 花崗岩の風化基岩がほぼ裸出したはげ山の場合でも 基岩への浸透は残るが，それを除いた雨水は地表面 流となり, 洪水ピークが大きくなる。堆積岩の里山 の場合は, 風化基岩のような貯留変動の大きい層を 持たないため, 原生林でも花崗岩山地よりも洪水流
出量が大きく基底流出量が小さい傾向がある。森林 土壤が失われた場合には, この傾向が極端になって 洪水流出量がより大きくなり, かつ, 乾燥時には流 出量がより小さくなる.

一方, 1960年代の燃料革命以降の里山放置により, 樹木が成長し, 樹種が変わり生態系が遷移してゆく 過程で, 蒸発散がどのように変化してゆくのかとい う点も重要な研究課題である. 日本は比較的湿潤気 候に恵まれ, 渴水被害はより乾燥した地域に比べれ ば深刻ではない。しかしながら, 近畿地方中央部か ら瀬戸内地方にかけては, 気象庁 (2011)によると, 年降水量の最小值生起年㧍よび1981 2010年平均値) が京都8 $81 \mathrm{~mm}$ (1994年, $1,560 \mathrm{~mm})$, 大阪 $819 \mathrm{~mm}$ $(1947,1,330 \mathrm{~mm})$, 岡山593 mm (1939, 1,132 mm), 広島 $740 \mathrm{~mm}(1978,1,541 \mathrm{~mm})$ という記録がある. か なりの乾燥年が見いだされるわけで, 岡山が特に乾 燥しやすいことがわかる。また, 化石燃料燃焼等に 伴う大気中温室効果ガス濃度上昇にともない, 渴水 
と洪水がいずれも激しくなることが推定されている (IPCC，2007）。そこで，森林蒸発散の特性，とり わけ, 里山放置林の蒸発散がどのように推移するの かは，森林管理上重要と言わなければならない.

そこで，長期にわたる気候と森林変化の両方が年 間蒸発散に及ぼす影響に関する研究の例を顧みる と, 東京大学愛知演習林では, 花崗岩のはげ山が緑 化された流域での流出が1930年代から現在まで継続 して測定されている。それに基づき，浅野ら（2005） は，年降水量には10-20年周期の変動があるとして いるが，年蒸発散量に対するその影響及び森林成長 の影響はいずれも小さいとしている。また, Kosugi and Katsuyama（2007）は，ヒノキ林を主体とする 桐生水文試験地流域の33年間の水収支から, やはり, 森林成長の蒸発散への影響は小さいとしている. 森 林伐採直後は, 明らかに蒸発散量が減少するのであ るが (Bosch and Hewlett, 1982)，その後人工林植栽 や放置した場合は, 数年から十数年経過した幼齢林 の段階で伐採前の蒸発散量状態に復帰する傾向があ るようである（Swank and Douglass, 1974; Farley et al., 2005). したがって, 数十年にわたる森林成長に 伴う蒸発散量の変化を見ると, 幼齢期の十年前後は 蒸発散量が小さく，その後はあまり変化しないよう に見える.しかし，50年以上の長期のデータでの解 析例はさすがに少ない。年の期間には気候も周期的 にあるいは, 温暖化のように一方向に変化するので, たとい植生条件が同じであっても蒸発散量が変化す る. また，小流域観測から流域水収支式を通じて得 られるものは年損失量であって, 年蒸発散量を推定 するには流域貯留量の変動を考慮しなければならな い，そのため，気候変化と植生変化の影響を評価す るには, 個別の要因の影響を, 十分慎重に分離解析 することが必要である。そこで，1947年にアカマッ 林が伐採されて以来現在まで放置されている，少雨 地帯岡山市郊外の森林総合研究所関西支所竜ノ口山 森林理水試験地における1937～2005年の69年間の水 文資料（森林総合研究所，2010）から北谷のデー夕 を解析し，その年間蒸発散量の推移を推定すること にした。ささら，植生変化の大きかった南谷流域の 年間蒸発散量について，基準となるべき北谷流域の 植生変化や気候変化の影響を考えた上で, 再検討を 加えた。

\section{II . 方法}

\section{1. 降水量・流出量のデータ}

森林総合研究所の竜ノ口山森林理水試験地は, 北 緯 $34^{\circ} 42^{\prime}$ 東経 $133^{\circ} 58^{\prime}$ の岡山市北東の郊外にあって, $17.3 \mathrm{ha}$ の北谷と $22.6 \mathrm{ha}$ の南谷からなる。標高 45 $257 \mathrm{~m}$ の古生層が主体で石英斑岩がこれを貫いてい る丘陵山地にあり, 粘土質の透水性の低い土壤に覆 われている。年降水量は約 $1,220 \mathrm{~mm}$ (1937-2005年 平均值)，年平均気温は $13.5{ }^{\circ} \mathrm{C} （ 1959 \sim 1984$ 年平均 值）である。すでに，1937～2005年の日単位の降水 量と北谷と南谷の両小流域の流出量がデータベース 化されており（森林総合研究所, 2010), 農林省林 業試験場 (1961), 関西支場防災研究室 · 岡山試験 地 (1979), 防災研究室 · 岡山試験地 (1981), 後藤 ら (2005), 玉井ら（2008）で公表されている。流 域図を図一1に，流域諸元を表一1に示す。流域の 詳細は, 武田 (1942), 藤枝・阿部 (1982), 阿部 · 谷（1985）などを参照されたい。

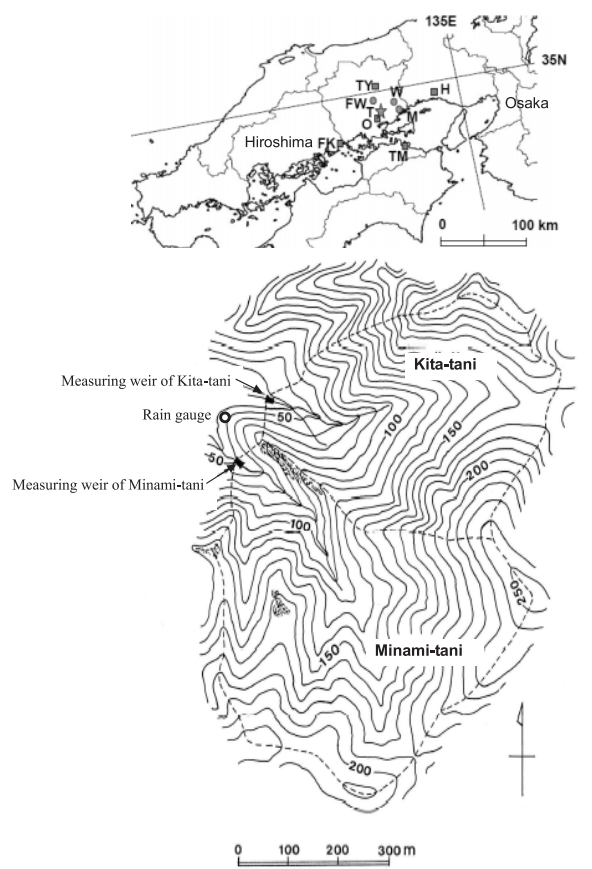

図 -1 森林総合研究所竜ノ口山森林理水試験地の流域図 $\mathrm{T}$ ：竜ノ口山, $\mathrm{O}$ ：岡山, $\mathrm{TM}$ : 高松, $\mathrm{TY}$ : 津山,

$F K$ : 福山, $H$ : 姫路, FW : 福渡, $W$ : 和気, $M$ : 虫明 Fig. 1 Map of the Tatsunokuchi-yama Experimental Forest of Forestry and Forest Products Research Institute.

T, Tatsunokuchi-yama; O, Okayama; TM, Takamatsu; TY, Tsuyama; FK, Fukuyama; H, Himeji; FW, Fukuwatari; W, Wake and M, Mushiake 
表 -1 竜の口山森林理水試験地試験地概要

Table 1 Description of the Tatsunokuchi-yama Experimental Forest.

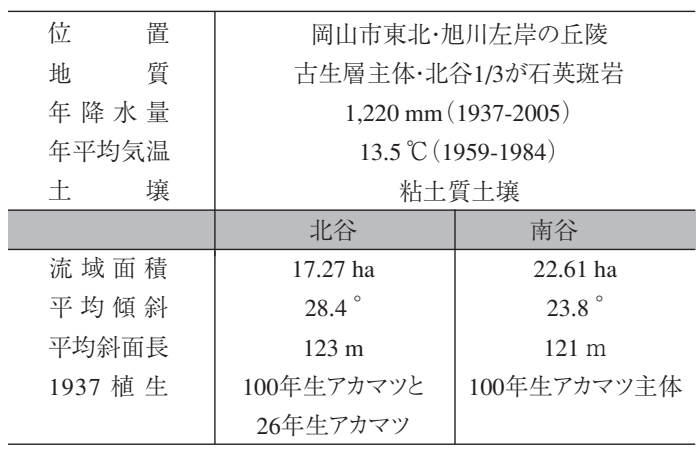

\section{2. 植生の変遷}

竜ノ口山の植生変化については, 後藤ら（2006） が詳しいのでこれを基に, 農林省林業試験場（1961） なども参照して概観する。主な植生変化は表一2に まとめられているが，植生の水循環への影響が本論 文の目的であるので, 植生の変化を以下に詳しく述 べておきたい。1937年開設当初の林相は，南谷の 17.6 ha $(78 \%)$, 北谷の9.8 ha (57\%) が100 120 年生のアカマツ老壮齢林, 残りの部分は, 南谷が 1926年伐採後のアカマツ天然更新地，北谷が26 29 年生のアカマツ幼齢林であった。しかし，1944年頃 にはマツ枯れ被害が激甚化し，1947年までに伐採さ れた。その後放置されたが，南谷では1954年に筋刈 り（植栽列に沿って下草を刈り払うこと）が開始さ れ，1957年までに主としてヒノキが植栽された。け れども，ネザサ・メダケの繁茂が著しく植栽木の生 育が悪かったので，再度植林のため1959年に枯殺剤 が散布された。これによって, ササ類が枯れている 状態にあった同年9月，山火事が発生した。南谷の 植生はほぼ完全に焼失したが，10月下旬にはネザサ 等の再生があって裸地状態は2ヶ月ほどであった。 北谷はアカマツ枯損伐採後放置されたが，植生繁茂 の密度は南谷よりも低く, 尾根付近の急傾斜部が露 岩状態になるなど, 植生回復が遅れていた。また, 1959年の山火事は類焼せず，2011年現在に至るまで 植生放置状態が続いている.

南谷では，山火事後の1960年にクロマツが植栽さ れ，樹高が1962年には1〜1.5 mに1976年には8.1〜 $9.5 \mathrm{~m}$ となり，樹冠の閉鎖した幼齢林となって順調 に成長した。しかし，マツ材線虫病の被害が現れ，
表-2 竜ノ口山試験地の植生変遷

Table Vegetation changes of the Tatsunokuchi-yama Experimental Forest.

\begin{tabular}{|c|c|c|}
\hline & 北谷 & 南谷 \\
\hline \multirow{2}{*}{1937} & アカマツ林 & アカマツ林 \\
\hline & 幹材積 $134 \mathrm{~m}^{3} \mathrm{ha}^{-1}$ & 幹材積 $157 \mathrm{~m}^{3} \mathrm{ha}^{-1}$ \\
\hline $1944-47$ & アカマツ枯れ伐採 & アカマツ枯れ伐採 \\
\hline $1948-1953$ & 放置 & 放置十ササ等繁茂 \\
\hline $1954-56$ & & ヒノキ植栽 \\
\hline 1959(9月) & & 山火事植生焼失 \\
\hline 1960 & 広葉樹成長 & クロマツ植栽 \\
\hline $1961-79$ & 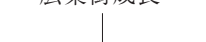 & クロマツ成長 \\
\hline 1980 & & クロマツ枯れ \\
\hline $1981-2005$ & $\nabla$ & 広葉樹成長 \\
\hline 2005 & 幹材積 $202 \mathrm{~m}^{3} \mathrm{ha}^{-1}$ & 幹材積 $135 \mathrm{~m}^{3} \mathrm{ha}^{-1}$ \\
\hline
\end{tabular}

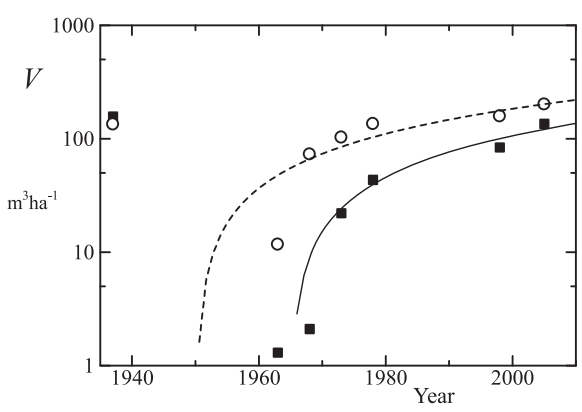

図-2 試験流域における流域平均幹材積 $(V)$ の変化 後藤ら (2006) 及び藤枝・阿部 (1982)により作成

$\bigcirc$ : 北谷実測, ------ $: V=-55263+7294.6 \ln (x), r^{2}=0.864$

：南谷実測, - $: V=-45913+6054.5 \ln (x), r^{2}=0.958$ ここで, $V$ : 幹材積 $\left(\mathrm{m}^{3} \mathrm{ha}^{-1}\right), x$ : 西暦年号, 回帰曲 線は, 1945頃のマツ伐採後の植生調査データから後藤ら （2006）が作成したもの

Fig. 2 Change in the catchment mean forest stand volume $(V)$ in the study catchments.

From Goto et al. (2006) and Fujieda and Abe (1982)

$\bigcirc$, investigated for Kita-tani; ---- $, V=-55263+7294.6 \ln (x), r^{2}=0.864$

, investigated for Minami-tani; $-V=-45913+6054.5 \ln (x), r^{2}=0.958$

In those equations, $y$ represents the catchment mean stand volume $\left(\mathrm{m}^{3} \mathrm{ha}^{-1}\right), x$ denotes the year. Regression curves were referred from a report by Goto et al. (2006) based on biomass investigations conducted after 1945.

1978年から1980年に $98 \%$ \%が枯損してしまい，その 後放置されている。な拉，沢沿い $12 \%$ はクズ等の ツル植物の被害を受けて病害に先立ちマツが枯れ， 源頭部17％は1974年に小規模の山火事があり，後 者の区域には1976年にヒノキが植栽された。 
後藤ら（2006）のまとめた，1960年頃以降の両流 域における幹材積の変遷に, 1937年頃のマツ林の デー夕も入れて，図一2に示す. 対数で書かれてい て幹材積が少ないときの増加が大きく表示されてお り，また，下草などが無視される点を配慮しなけれ ばならないが，北谷は1968年までに，南谷は1973年 までに，急成長していることがわかる。また，1947 年から放置された北谷の植生成長に，1959年に山火 事のあった南谷のそれが遅れて追随して，まだ追い ついていないように見える。このように，北谷は 1948年から放置されてきたが，南谷は短期間で植生 変化を繰り返し, 結局クロマツ幼齢林が枯損した 1980年以降ほぼ放置された。後藤ら（2006）による 2005年植生調査では，北谷は，ほぼ全域が樹高10～ $15 \mathrm{~m}$ 程度のコナラを主とし, カスミザクラ, ヤマザ クラなどの落葉樹や, ヒサカキ, ネズミサシ, ソヨ ゴ，クロガネモチなどの常緑樹を交えた落葉樹主体 の常落混交広葉樹林で, 幹材積 $202 \mathrm{~m}^{3} \mathrm{ha}^{-1}$ であった。 南谷流域の $2 / 3$ は, 樹高 $15 \mathrm{~m}$ 程度のクスノキ, $10 \mathrm{~m}$ 程度のシラカシの他，ヒサカキ，ヤブニッケイ，リヨ ウブ，カスミザクラなど主に常緑樹の多い常落混交 広葉樹林で占められた。これと76年植栽のヒノキ林 が幹材積の多い区画であるが，アカメガシワやヤブ ニッケイ等の材積の小さい広葉樹林の区画，2004年 の台風被害で無立木になった区画がある.そのため, 2/3を占める広葉樹林での幹材積は北谷に近くなって いるが，流域全体で平均すると $135 \mathrm{~m}^{3} \mathrm{ha}^{-1}$ であった。

\section{3. 欠測補正}

竜ノ口山試験地の欠測については，下記のように

表 -3 試験流域流出量の欠測推定

Table 3 Estimation of the runoff rate during periods of missing data in the study catchments.

\begin{tabular}{|c|c|c|c|c|}
\hline \multirow{2}{*}{ 欠測期間 } & \multirow{2}{*}{ 欠測流域 } & \multirow{2}{*}{$\begin{array}{c}\text { 降水量 } \\
\mathrm{mm}\end{array}$} & \multicolumn{2}{|c|}{ 観測·推定流出量 mm } \\
\hline & & & 北谷 & 南谷 \\
\hline $1967 / 6 / 24-7 / 25$ & 北谷 & 353.0 & $(140.0)$ & 177.1 \\
\hline $1974 / 6 / 6-7 / 16$ & 南谷 & 334.0 & 114.9 & $(81.6)$ \\
\hline $1991 / 2 / 20-3 / 8$ & 南谷 & 85.0 & $(9.8)$ & $(13.1)$ \\
\hline $1991 / 2 / 27-3 / 8$ & 北谷 & 28.0 & (7.6) & $(9.8)$ \\
\hline $1995 / 12 / 19-12 / 31$ & 北谷·南谷 & 3.0 & $(0.6)$ & $(1.3)$ \\
\hline 1996/1/1-1/10 & 北谷-南谷 & 9.5 & $(0.8)$ & $(1.3)$ \\
\hline $1996 / 2 / 13-3 / 4$ & 北谷·南谷 & 34.0 & (2.1) & $(4.0)$ \\
\hline $1997 / 7 / 13-8 / 8$ & 南谷 & 219.0 & 106.3 & $(89.4)$ \\
\hline $2005 / 1 / 31-2 / 9$ & 北谷 & 0.0 & (1.1) & $(1.9)$ \\
\hline $2005 / 2 / 3-2 / 9$ & 南谷 & 8.7 & $(1.2)$ & $(2.2)$ \\
\hline
\end{tabular}

補正した。降水量の欠測期間はなかったが，表一3 のように，流出量に関して北谷で5期間，南谷で 6 期 間の欠測期間があり（1995年12月19日から1996年 1月10日まで年をまたがった期間が含まれている)， HYCYMODEL（福嶌・鈴木，1986）を用いて補正 した。 そのパラメー夕は, Tani et al. (2011) が竜) 口山北谷（KT）に対して最適化した值を南谷も含 めて用いたが，欠測前後の期間の観測流出量で部分 的に修正した。また，このパラメータは1時間で計 算するため，日デー夕を24等分して計算に用いた。 なお，降水量の大きかった欠測期間も含まれている ので, モデルでの推定䛊差が解析に及ぼす影響を小 さくするように留意した。すなわち，欠測期間を含 む連続した数年間の水収支を推定する必要がある場 合にのみ推定值を使用し, その必要のない場合は, 降水量が $100 \mathrm{~mm}$ 以上ある久測期間を含む年を解析 から除外した。

\section{4. 年平均気温の長期変化推定方法}

流域の蒸発散量は植生の成長・伐採によって変化 し, なおかつ, 気象条件に応じて变化する. 数十年 を対象とすると，その両方が絡み合って影響を及ぼ すであろう. Penman-Monteith式などの詳細な蒸発 散モデルを使った解析もあり得る（Monteith, 1965). しかし, 本稿では, 年単位の水収支式によって降水 量から流出量を差し引いた年損失量の長期変化を調 べることに解析の焦点をあて, 植生変化と年平均気 温の及ぼす影響について, ベーシックな解析を試み た。ただし, 竜ノ口山試験地の気温のデータが入手 できなかった年も多かったので, 周辺の気象台やア メダスのデータを比較したうえで，次のように年平 均気温を推定することとした。それには, 林業試験 場関西支場年報（林業試験場関西支場，1960～1985） や気象庁データベースを用いた。ただ，岡山気象台 が1982年に場所移転があった影響があり（近藤， 2009), 都市化ヒートアイランドの影響が各観測所 毎に異なることも問題であったので, 岡山, 高松, 津山, 福山, 姫路各気象台と, 福渡, 和気, 虫明の アメダスのデータを参考に推定した. 図一3に, 気 象台観測值と竜ノ口山の推定結果を示す。図一3の 上図は各気象台の年気温变化であるが, 眓にGap 表示したように, 岡山の場所移転による気温急上昇 が見られた。これを除き1950年頃と2000頃の年平均 気温を比べる, 高松の上昇が大きく, 内陸の津山 の上昇が小さく, 福山, 姫路の上昇が両者の中間に 


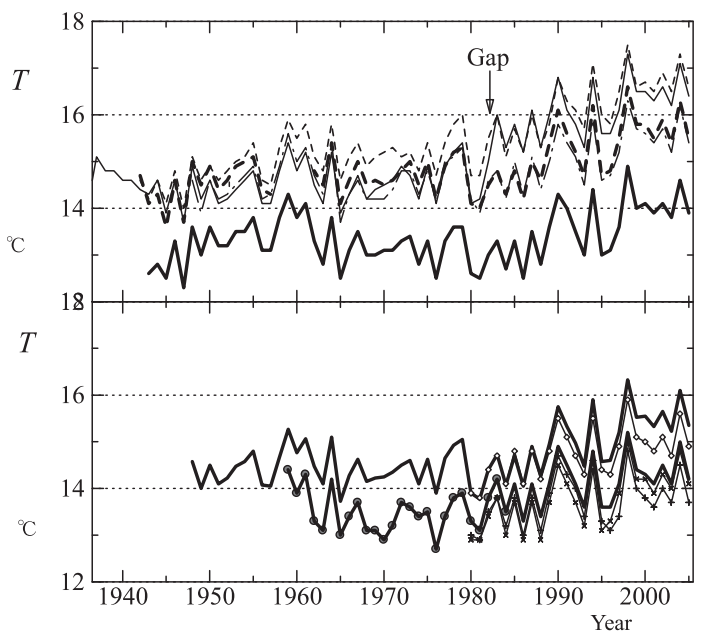

図 -3 竜ノ口山付近の年平均気温の長期変動 上図：一：岡山, ---- : 高松, — : 津山, --- - : 福山, -・- : 姫路

なお，Gapは岡山における1982年の場所移転による急 な上昇を示す。

下図：○：竜ノ口山露場実測，一：竜ノ口山推定, —: 高松, 津山, 福山, 姫路の平均,

-+- : 福渡, $-\mathrm{x}-$ : 和気, $-\diamond-$ : 虫明

Fig. 3 Long-term change in the annual air temperature $(T)$ around Tatsunokuchi-yama

Upper :- - Okayama; ---- Takamatsu; —- Tsuyama; - - - Fukuyama; - - -, Himeji

A mark of 'Gap' shows a change of Okayama temperature attributable to relocation of the observatory.

Lower: •, Observed at the Tatsunokuchi-yama observation field; - Estimated for the Tatsunokuchi-yama;

—, Averaged of Takamatsu, Tsuyama, Fukuyama and Himeji. -+- , Fukuwatari; $-\mathrm{x}-$, Wake; and $-\diamond-$, Mushiake

なる。㧍そらく都市化の効果が津山で小さく, 高松 で大きいと推定される。下図には, 高松, 津山, 福 山, 姫路の気象台の平均値とアメダス3地点の74年 以降の值を, 竜ノ口山露場の実測值とともに示した. 支場年報に記された竜ノ口山露場の気温は4地点の 平均值より $1{ }^{\circ} \mathrm{C}$ ぼ低くなっている。また，アメダ ス3地点の気温は1990年代から、高松等4気象台の平 均值よりも上昇傾向が小さい。これは, 各気象台が 都市の中央にあってヒートアイランドの効果を強く 受けているのに比べて，アメダスが郊外にある差が 現れたものと推定される。以上の傾向を基にして、 竜ノ口山に㧍ける1959年以降の年平均気温を次のよ うに推定した。1959～79年については露場での観測 值をそのまま使用したが，欠測の1964年については 1962 66年に扔ける露場観測值と高松等4気象台平 均值との差の平均が $0.9{ }^{\circ} \mathrm{C}$ であることから推定した.
また，露場のデータとアメダス 3 地点のデータが重 なって存在する期間（1980～84）に扔いて, 露場デー 夕とアメダス 3 地点の平均気温が毎年 $0.1{ }^{\circ} \mathrm{C}$ 以内の差 であってほぼ等しかったことを利用して，1985年以 降の竜ノ口山の年平均気温をアメダス3地点の平均 值として推定した。こうして得られた竜ノ口気温は、 気温1960年頃が高温であるが，その後60年代から70 年代にかけて低温である点, 80 年代後半以降の高温 である点は, 周辺各地の一般的な傾向とほぼ対応し ている。このように，1959年以降は竜ノ口山の気温 変動傾向が周囲のものとほぼ一致しており, 蒸発散 への影響を検討する目的においてこの值を使用して 差し支えないと判断した.

\section{5. 長期トレンドの表示方法}

一般に気象・水文の要素は, 年々変動の他に長期 間のトレンドがみられる。そこで，細かい変動を均 して長期トレンドを把握するため, 気候変動研究で しばしば用いられてきた偏差積算曲線（Cumulative anomalies curve) (Lozowski et al., 1989; Ding et al., 2007）をグラフへの表示方法として採用することに した。この方法では, 期間の年数を $n$, その期間の 変数 $x$ の平均值を $\bar{x}$ と, 平均值からの偏差を最初 から $i$ 年目まで次式で積算する。

$$
f_{i}=\sum_{k=1}^{i}\left(x_{k}-\bar{x}\right)
$$

この值を図示すれば折れ線が得られる. 年々变動に よる凹凸はあっても, 変数 $x$ の值が平均值 $\bar{x}$ よりも 大きい（高い）傾向のある期間は，折れ線は上昇し， ほぼ平均值に近い傾向の期間は水平に, 小さい（低 い）傾向の期間は下降する。つまり，正の1に揭げ る図ー4にみられるように, 勾配によってトレンド を認識することができる，以下ではこの表示によっ て，年々変動傾向を調べることにしたい.

\section{6. 貯留量変動を考慮した年蒸発散量の推定方法}

年蒸発散量は，年を単位とした流域水収支式によ り推定される場合が多い (Kosugi and Katsuyama,

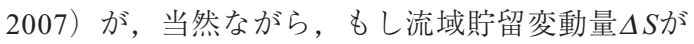
プラスならば, 降水量 $P$ と流出量 $Q$ の差で定義され る損失量 $L$ は, 蒸発散量 $E$ に比べて $\Delta S$ だけ大きくな る。すなわち，水収支は次のように表される。

$$
L=P-Q=E+\Delta S
$$

例えば，少雨年で貯留量が減少すれば $\Delta S$ はマイナ 
スになり，Eは観測で得られるLよりも $\Delta S$ の絶対值 だけ大きくなる

とくに，日本の中では少雨傾向の強い瀬戸内にあ る竜ノ口山では, 貯留変動の扱いに慎重な配慮が必 要であることがわかっている（谷・阿部，1987）. 流域貯留量の実測は著しく困難で，かつ土畩水分や 地下水位のデー夕もないため, 本論文では, 短期水 収支法において蒸発散量の季節変化を推定するとき 用いられる仮定，すなわち，基底流出量の值を貯留 量の指標として用いる仮定（鈴木，1985）を年単位 においても適用することにした。ここでは，年末年 始の降水量が少なくて水年を暦年と一致させること に問題がないとみられるので，原則的には12月31日 の日流出量を調べてその年の貯留量の指標とする. ただし，直前に降水があった場合には，12月31日よ り前で最も近い基底流出期間の日流出量を代わりに 用いることにした。こうして貯留量を年末の基底流 出量で代表させるとすれば，等しい年末基底流出量 の值を持つ期間は, 水収支式における貯留変動項が ゼロになり, その期間平均の年蒸発散量が, 降水量 と流出量の差から推定できることになる。そこで, 本論文では，この手法を適用して，年蒸発散量を推 定することにした。

\section{III. 結果}

\section{1. 気象条件と年損失量の長期変動}

図一 4 に, 年降水量, 年平均気温, 北谷と南谷の 年損失量を，それらの偏差の積算值とともに示す。 IIの5の定義から、偏差の積算値は, 絶対值には意 味がなく勾配が重要であって, これが数年から十数 年にわたる傾向を意味している。な拝，気温につい ては，全期間のデータがないので，(1）式の期間平 均值としては，1959２005年の平均值を採用して表 示した。年降水量については，あまり明確な長期傾 向はないが，図に示すように，1940～50年は平均並 み，1967～88年も平均並み，1994～2002年は少雨な どの他は，より短い期間で多雨少雨が交替する傾向 が見られる。年平均気温は, 連続して1943年から デー夕のある津山気象台も示したが，長期変動傾向 が，1959年以降，竜ノ口山推定值とほぼ一致してお り，両者とも次のような傾向である。すなわち， 1965～81年は低温，1990年以降は高温という明確な 長期変動があり，1959～61年はやや高温である. 1982 89 年は竜ノ口山は平均程度, 津山は低温傾
向が続くところがやや異なるが，1970年代から 1990 年代への温暖化過度期とみることはできよう。

次に, 単年の水収支式に抢いて蒸発散量と貯留変 動（増加）の合計としての意味を持つ年損失量の長 期変動を，北谷・南谷を対象にみておこう。まず, 1937～43年までは平均並みであり，これは，北谷南 谷に共通である。また，1992２005年の期間は両者 とも損失量が平均值よりも大きく, やはり北谷南谷 に共通である，植生変化の少ない北谷でみると，マ ツ枯損後の1944年以降は伐採が終了する1947年を待 たずに損失量が小さくなり，1957年くらいまでは平 均よりも損失量が小さい傾向があるが，1958年頃か ら損失量が平均程度になっている。1969年頃より 85 年までは再び損失量がやや小さくなっており，その 後1988年頃より2005年までの損失量が平均よりも大 きいように転じている．南谷の年損失量の変化を見 ると，それには植生変化が大きく影響している傾向 が見られる。1945年前後の傾向はアカマツ林の枯損 が共通であるため北谷と同じだが，1948年から1954 年までは損失量が平均的であって, 北谷が平均值よ り小さいのと異なっている。 ヒノキ植栽が行われて いた1955年から1959年まではやや小さく，1959年の 山火事後はより小さくなったが，マツが成長してき た1968年頃から平均よりも大きい傾向に転じてい る. 1980年のマツ枯損後は, 損失量が再び小さい傾 向が1985年まで続き，1995年くらいまでは平均的， それ以降は大きくなっている。また，1995年頃から 北谷と年々変動がほぼ一致し，絶対值は北谷よりも わずかに大きい傾向で推移している。

\section{2. 単年の水収支における貯留量変動の影響}

IIの6で（2）式を用いて説明したように，年水収 支において, 損失量 $(L)$ は, 蒸発散量 $(E)$ より も流域貯留量の増加分 $(\Delta S)$ だけ大きく, 減少分 だけ小さい。竜ノ口山では少雨気候を反映して, 観 測期間中の年降水量の最小值は1939年の $622 \mathrm{~mm}$ と いう小さい值が得られている。その年の流出量は北 谷で50 mm, 南谷で $52 \mathrm{~mm}$ であったため, 損失量は, 北谷と南谷で, $572,570 \mathrm{~mm}$ の值と計算される。こ のように，極端な少雨年では，入力降水量ですら通 常年の蒸発散量をはるかに下回り, 貯留量の減少量 $\Delta S$ が水収支に及ぼす影響は無視できないと推定さ れる. そこで，この少雨年を含む期間の北谷の水収 支変動を例に, 貯留量変動の水収支に及ぼす影響を 調べてみた。 

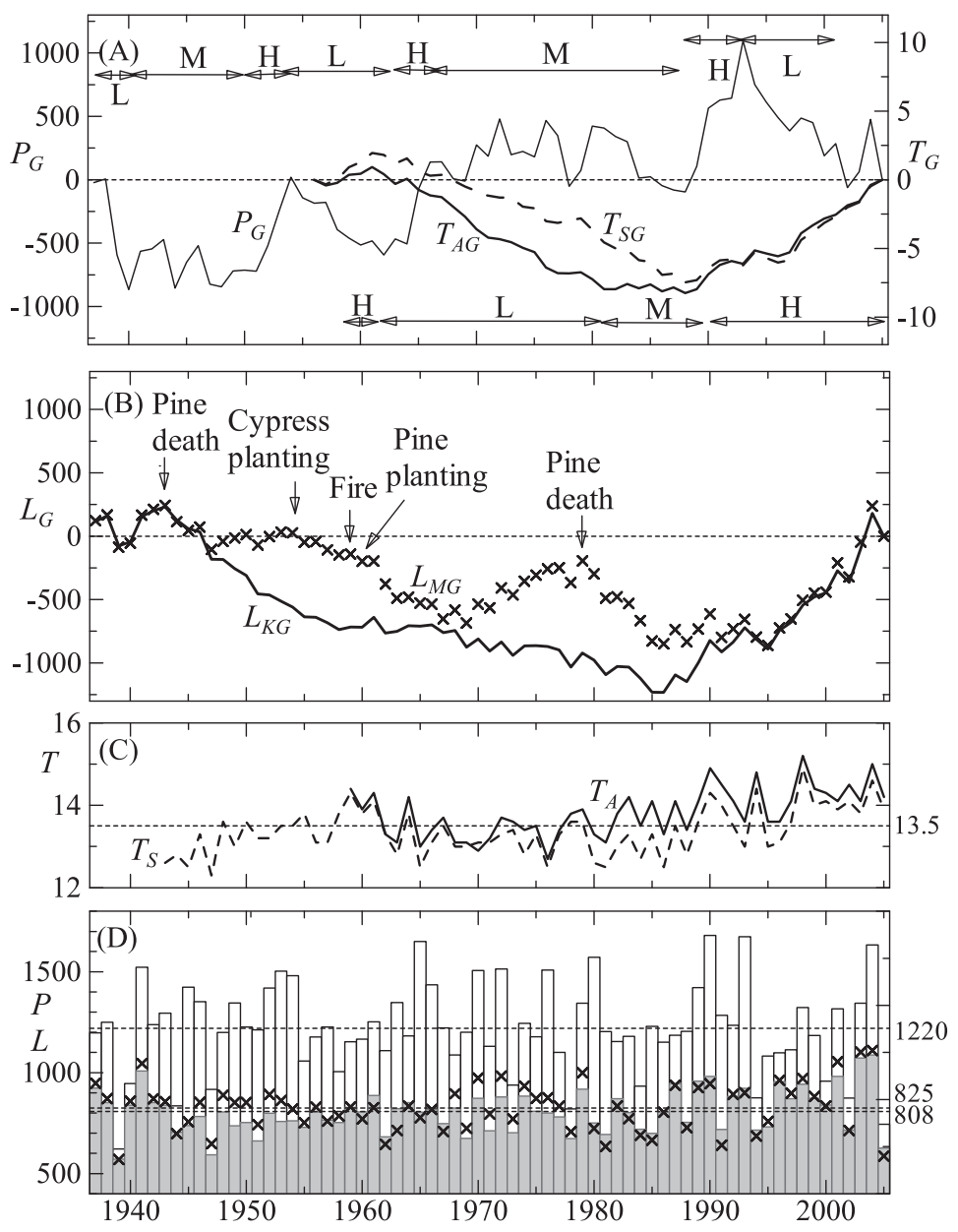

図-4 年平均気温, 年降水量，年損失量の長期変動

(A) : 竜ノ口山気温 $\left(T_{A G}\right)$, 津山気温 $\left(T_{S G}\right)$, 年降水量 $\left(P_{G}\right)$, (B) : 年損失量 (北谷: $L_{K G}$, 南谷 $\left.: L_{M G}\right)$ の偏差積算曲線, (C) : 竜ノ口山気温 $\left(T_{A}\right)$, 津山気温 $\left(T_{S}\right),(\mathrm{D})$ : 降水量 $\left(P\right.$, 白色棒グラフ), 損失量 (北谷: $L_{K}$, 灰色棒グラフ, 南谷: $L_{M}, \times$ 印). (C), (D)の横線は，平年值を示す。

Fig. 4 Long-term changes in the annual air temperature, precipitation and loss.

(A) Cumulative anomaly curves of air temperature in Tatsunokuchi-yama $\left(T_{A G)}\right.$ and Tsuyama $\left(T_{S G}\right)$ and precipitation $\left(P_{G}\right)$. (B) Cumulative anomaly curves of loss for Kita-tani $\left(L_{K G}\right)$ and for Minami-tani $\left(L_{M G}\right)$. (C) Air temperature values in Tatsunokuchi-yama $\left(T_{A}\right)$ and Tsuyama $\left(T_{S}\right)$. (D) Precipitation $\left(P\right.$, white bar) and losses for Kita-tani $\left(L_{K}\right.$, gray bar) and Minami-tani: $\left(L_{M}\right.$, cross). Horizontal lines in (C) and (D) represent values in a normal year.

図ー5は，少雨の1939年を含み，北谷がアカマツ 林で扔扔われていた1937年から1943年までの年水収 支と年末12月31日の日流出量を示したものである. この年末流出量は, 流域貯留量を代表する基底流出 量とみなしたが，データのない1936年12月31日につ いては，その代わりに1937年1月1日の日流出量を用 いた。また，年末に降水があった $41 ， 43$ 年は，それ ぞれ, 降水直前の12月20日, 29日の日流出量を用いた。 さて，この7年間の年損失量Lは，平均值 $841 \mathrm{~mm}$ （図
に点線で表示）に近い場合（1938，1940，1942， 1943年), 平均より大きい場合 (1937，1941年), 平 均より小さい場合（1939年）が区別される。これに 対して, 年末の基底流出量は, 損失量が平均に近い 1938，1940，1943年では変化が小さく，損失量が大 きい1937，1941年に増加し, 損失量が小さい1939年 に減少して抢り，1942年を除いて，明瞭な対応がみ られる。42年については, その損失量が平均的であ るのに, 基底流出量が減少している。これについて 
は，1941年12月の月降水量が $65 \mathrm{~mm}$ で比較的大きかっ た影響が考えられる。すなわち，12月20日にさかの ぼってその流出量の值を年末基底流出量としてはい るが，それでもその前の降水によって基底流出量が 大きくなっていたと考えられる。図一5における 1941年末の流出量のプロットはそのときの貯留量を 過大に評価していると推定される.

このように, 図一5の結果から, 年末流出量の変 化はその年の貯留量の増減を良く表しており, 貯留 量変動の小さい年の年損失量は年蒸発散量に等しい とみられることがわかる。 また，この期間で降水量 が二番目に少ない1940年でも損失量が平均的であ り，かつ年始年末の基底流出量の差が小さいことか ら, 蒸発散量の抑制は少ないとみられる。極端な少 雨年の1939年においても，貯留量減少によって損失 量よりも大きい蒸発散量がまかなわれているとの推 定ができる。1939年に貯留量が減少し，1940年には 貯留量が小さいまま推移し, 多雨年の1941年に貯留 量が回復したと考えられる。1941年の損失量が平均 よりも大きいのは，(2) 式に基づくと，それが貯留 量の回復分だけ蒸発散量に比べて大きくなったとみ なすのが妥当と考えられる。少雨年に蒸発散量が抑 制され，多雨年に遮断蒸発量が大きくなる可能性 （近藤ら，1992）や気候変動の影響もあるだろう。 しかし, 貯留量の変動が少雨年の損失量を蒸発散量 よりかなり小さくしていることは確実である。これ

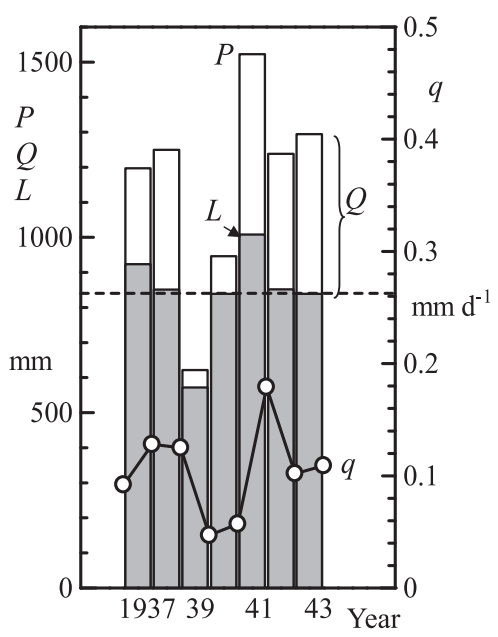

図－5 1937～1943年の降水量，年損失量，年末基底流 出量の変化

Fig. 5 Changes in the annual precipitation $(P)$, runoff $(Q)$, loss $(L)$ and runoff rate at the end of year $(q)$ during 1937-1943.
まで，少雨年に損失量の観測結果に基づいて蒸発散 量がきわめて小さくなるとの表現はしばしば見ら れ，竜ノ口山でも指摘されている(例えば，中野， 1976)。しかし, 森林からの年蒸発散量の推定にお いて, 貯留量変動の影響評価が重要であることには 十分注意をはらわなければならない。

\section{3. 年蒸発散量の年平均気温に対する関係}

放置によって広葉樹が自然に成長してきた北谷の 蒸発散量の経年変動を調べるため, IIの6の方法に 従い, 年末流出量の等しい時点ではさまれた期間の 平均年損失量を計算して表一4に示した。その期間 の貯留量変化は小さいとみなすことができるので, 年損失量は年蒸発散量の期間平均値を表すと見て差 し支えない. そこで, 表に示された蒸発散量とその 期間の年平均気温との関係を図一6の左図に示した. 気温の変化幅は小さいものであるが, 蒸発散量と気 温には図に示すとおり正の相関がある。また，A期 間（1958～68年）からB期間（1969～81年）で損失 量が気温低下に対応していったん減少し，C期間 （1982～89年）で気温上昇に対応して損失量が増加 している結果は, この期間の蒸発散量の変化が植生 成長にかかわらず，気温によって説明できることを 示唆している. 北谷のこの期間の蒸発散量の気温依
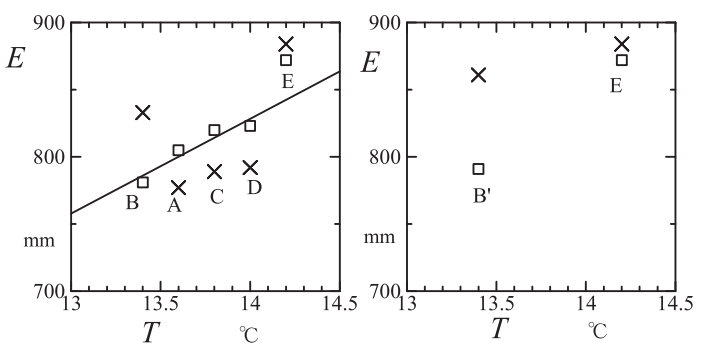

図-6 水収支期間平均の年蒸発散量の年平均気温に対 する関係

$\square$ : 北谷, $\times$ : 南谷

図中の記号は表一4の各期間に対応

直線は, $\mathrm{A} \sim \mathrm{D}$ の期間の北谷における気温 $T$ と蒸発散量 $E$ の回帰 $E=65.5 T-95.6$ を示す.

左図は，A〜Eの期間を，右図は，B’と $\mathrm{E}$ の期間を表示し ている。

Fig. 6 Relation of annual evapotranspiration to the annual air temperature during each water balance period.

$\square$, Kita-tani; $\times$, Minami-tani. Letters coincide with those of the water balance period in Table 4 . The regression line in the figure is for evapotranspiration and air temperatures for periods A-D.

Left panel: relations for periods A-E. Right panel: relations for periods B' and E. 
存性についてはINの1で検討を加える.

また，表一4，図一6には，北谷の水収支期間を 基に，南谷の結果も併せて示している。これらは, INの3で, 南谷の蒸発散量に対する植生変化の影響 について，気温依存性を考慮したうえでの検討を行 う際に参照する。

\section{4. 貯留量変動に及ぼす植生変化の影響}

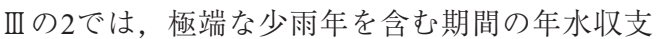
式を調べて，年末の基底流出量の増減で指標化され た貯留量の変化が年損失量に大きな影響を与えてい ることを明らかにした。そこで，解析対象を観測全
期間に拡大して，単年における年末基底流出量の増 減と損失量との関係を，図一7，8に示す。なお， 図に含まれる期間内に扔いて，1967年の北谷，1974 年と97年の南谷は，降水量が $100 \mathrm{~mm}$ 以上ある欠測 期間を含むので，プロットから除いた。さてて，これ らの図のように, 北谷と南谷の年末基底流出量の増 減と損失量の関係を, 植生状態の異なる期間毎に表 示すると，その関係は植生状態によって異なるとい う，一見理解しづらい結果になった。すなわち，各 プロットは，年降水量によって区分けしているが, 植生状態が森林である時には, 基底流出量の増加す る年に損失量が大きく, 減少する年に小さくなって,

表－4 短期水収支法の応用による北谷の年平均蒸発散量とその期間に対応する南谷の年平均蒸発散量

Table 4 Annual evapotranspiration of Kita-tani catchment estimated by application of the short-term water budget method and that of Minami-tani catchment in the corresponding period.

\begin{tabular}{|c|c|c|c|c|c|c|c|}
\hline & \multirow{2}{*}{ 期 間 } & \multirow{2}{*}{$\begin{array}{c}\text { 降水量 } \\
\mathrm{mm} \\
\end{array}$} & \multirow{2}{*}{$\begin{array}{c}\text { 気温 } \\
{ }^{\circ} \mathrm{C}\end{array}$} & \multicolumn{2}{|c|}{ 期間前後の年末基底流出量 $\mathrm{mmd}^{-1}$} & \multicolumn{2}{|c|}{ 蒸発散量 $\mathrm{mm}$} \\
\hline & & & & 北谷 & 南谷 & 北谷 & 南谷 \\
\hline $\mathrm{A}$ & $1960-1968$ & 1237 & 13.6 & $0.112-0.120$ & $0.262-0.120$ & 805 & 777 \\
\hline $\mathrm{B}$ & 1969-1981 & 1251 & 13.4 & $0.120-0.120$ & $0.120-0.215$ & 781 & 833 \\
\hline $\mathrm{C}$ & 1982-1989 & 1182 & 13.8 & $0.120-0.120$ & $0.215-0.215$ & 820 & 789 \\
\hline $\mathrm{D}$ & 1984-1991 & 1261 & 14.0 & 0.091-0.091 & $0.196-0.178$ & 823 & 792 \\
\hline $\mathrm{E}$ & 1992-2001 & 1186 & 14.2 & $0.091-0.091$ & $0.187-0.115$ & 872 & 884 \\
\hline $\mathrm{B}^{\prime}$ & 1969-1979 & 1226 & 13.4 & $0.120-0.214$ & $0.120-0.174$ & 791 & 861 \\
\hline
\end{tabular}
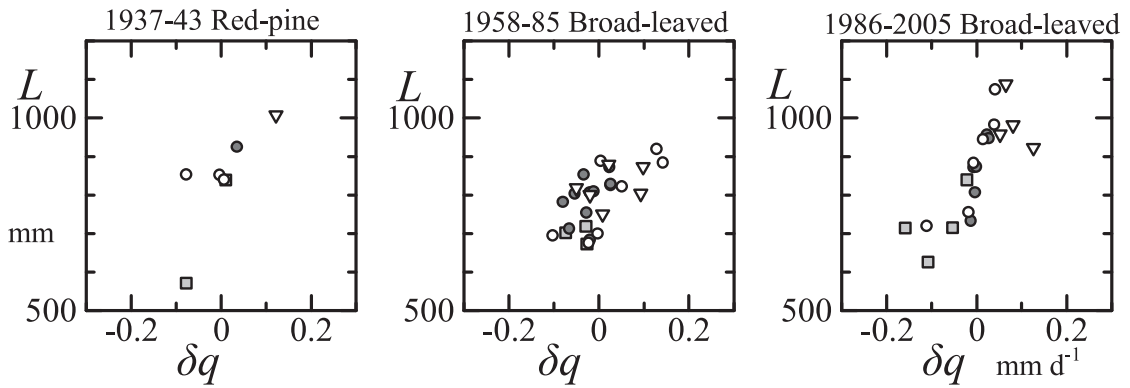

1944-57 After clear cutting

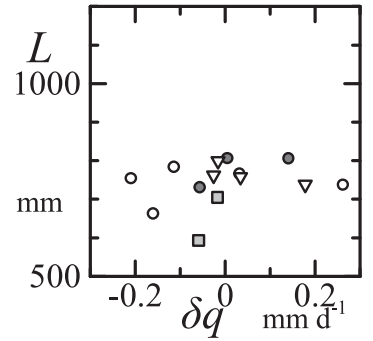

Annual precipitation

$\quad<1000 \mathrm{~mm}$

$\circ \quad<1200$

$\circ \quad<1400$

$\nabla \quad>=1400$

図-7 北谷における年末基底流出量の増減 $(\delta q)$ と年損失量 $(L)$ の関係 記号は年降水量 $(P)$ による区分を表す.

Fig. 7 Relation of annual loss $(L)$ to difference of baseflow runoff rates between the beginning and end of a year for Kita-tani catchment. Symbols show annual precipitation ranges. 
1937-43 Red-pine

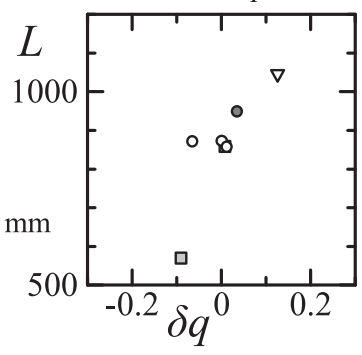

1968-79 Black-pine

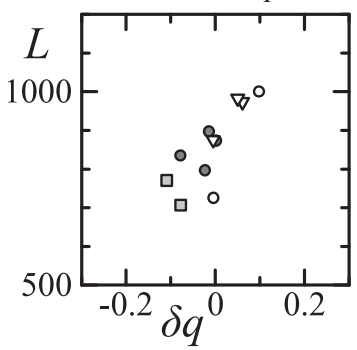

1986-2005 Broad-leaved

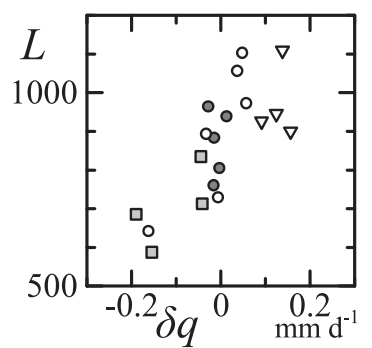

1944-57 After clear cutting

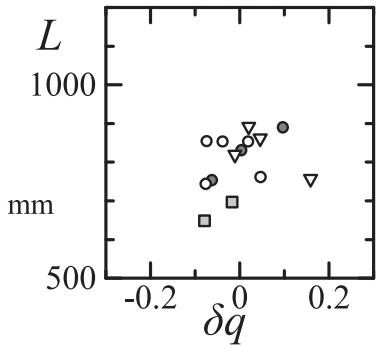

1960-67After wildfire

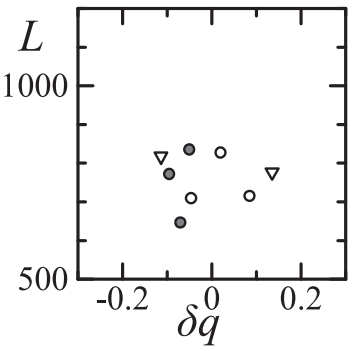

1980-85 After pine death

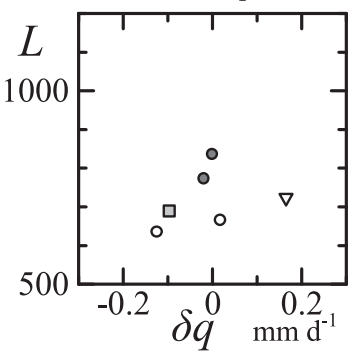

図 -8 南谷における年末基底流出量の増減 $(\delta q)$ と年損失量 $(L)$ の関係 記号は図一7と同じ

Fig. 8 Relation of annual loss $(L)$ to difference of baseflow runoff rates between the beginning and end of a year for Minami-tani catchment. Symbols are the same as those for Fig. 7.

両者に正の相関があることがわかる，他方，森林が 枯損するなどによって回復していない時期には，損 失量の絶対值が森林の時期よりも小さい傾向はある ものの, 年末基底流出量増減によって損失量が変化 する傾向はほとんど見られないし，降水量の大きい 年に損失量が大きい傾向もない。（2）式に示す水収 支の原理から, 損失量が大きいことの原因は, 蒸発 散量が大きいかまたはその年の始めと終わりで貯留 量が増加しているかの2つを考えなければならない が, 森林の場合と森林未回復の場合に差が見られる のはなぜなのか， IVの2で考察を加える.

\section{IN 考察}

\section{1. 年平均蒸発散量の気温依存性}

1937〜2005年の平均損失量は, 北谷が808 mmで 南谷が $825 \mathrm{~mm}$ であった。 これらの值は, 両方の流 域における蒸発散量の平均的な值と考えられる。滋 賀県にある桐生試験地ヒノキ林小流域の33年間の水 収支観測結果からの推定值が749 mm（Kosugi and Katsuyama, 2007）であり, 愛知県にある白坂試験地 二次林流域の $1930 \sim 90$ 年平均が $856 \mathrm{~mm} ゙$ ある（愛
知演習林 - 演習林研究部, $1976 ; 1977$; 愛知演習林, $1981 ； 1984 ； 1987 ； 1999 ）$ のと比べて, 当地の森林 蒸発散量として妥当な範囲の值とみてよい。ところ で, 南谷が北谷より平均損失量が $17 \mathrm{~mm}$ 多い理由に ついては, 図一1に示すように, 南谷の斜面は北谷 よりも北向き傾向があり, 日射量・蒸発散量を小さ くする要因になるはずなので, 斜面向きからは説明 できない。白原因については, 両者の地下の水貯 留構造が反映していると考えられる。すなわち, 北 谷には堆積岩以外の石英斑岩の比率が $1 / 3$ あり, 斜 面勾配が急でかつ土壤がうすい（武田，1942； Tamai, 2010）ことによると推測される。この点は, IVの3で北谷を基準とした南谷の植生変化の蒸発散 量に及ぼす影響を検討する際に参照する。

IIIの3では，1960年から2001年までの期間で，貯 留量変動の小さいとみなされる数年間の年損失量か ら推定された北谷の年蒸発散量が気温によって説明 されることを述べた（図一6)。こうした蒸発散量の 気温への依存性について考察を加える. 図一6内に 引かれた回帰直線は，1960９1年の期間における $1{ }^{\circ} \mathrm{C}$ の気温上昇に対する年蒸発散量増加が70 mmである ことを示している。そこで，植生条件が同じ場合， 
年平均気温が $1{ }^{\circ} \mathrm{C}$ 高いときにどのくらい蒸発散量が 大きくなると見てよいのだろうか. 実証的な研究は これまでなされていないが, 蒸発散モデルを用いた 感度分析研究が参考になる。例えば, Irmak et al. （2006）は，米国内の気候条件の異なる地域で気候 条件が蒸発散量に及ぼす影響をPenman-Monteith式 の感度分析によって調べており，気温 $1{ }^{\circ} \mathrm{C}$ 上昇によ り比較的湿潤なフロリダ (降水量 $1,234 \mathrm{~mm}$ ) で年間 $30 \mathrm{~mm}$ 弱の増加と推定している。 また, 三浦・諸泉 （2004）はPenman式を用いて岡山の気候での可能蒸 発散量への影響評価を行っており，1 $\mathrm{C}$ の気温低下 が年間 $33 \mathrm{~mm}$ と推定している。これらのことから, 1960～91年の期間に扔いて検出された $1{ }^{\circ} \mathrm{C}$ 上昇に対 する70 mmの蒸発散増加という結果は気温だけで説 明するには大きいように見える。ただ，B期間を除 き， $\mathrm{A} ， \mathrm{C}, \mathrm{D}$ 期間では勾配は緩くなり，上記のモ デルの傾向程度である。平均年降水量が期間毎に異 なっていることから, 年平均気温だけで気象条件を 代表させられないので, 北谷での上記結果が過大と は言えないかもしれない。しかしながら，1992年以 降は年蒸発散量がさらに大きく増加していることは 注目すべきである。これについては，図一2で幹材 積の増加傾向を見ると，1970年代に急増して，80， 90 年代は増加が頭打ち, その後 2000 年代に入って幹 材積は再度増加を示しているので，このことが反映 されているのかもしれない.図一4に扔いて, 南谷 でも北谷と同じ共通の傾向で年損失量が推移してい ることから，1990年代以降に蒸発散量が増加してい る傾向そのものは確実と考えられる(図一4).また, 愛知演習林の白坂流域でも, 1988年以降に年蒸発散 量が70 mm以上増加しているとの最近の報告もある (田中・蔵治，2011）。これらのことから，こうした 蒸発散量の近年の増大は広く一般的に見られる可能 性がある.なぜこうしたことが起こっているのかは, 気候温暖化影響として今後追求すべき, 大きな森林 水文学のテーマであるだろう。

\section{2. 少雨乾燥に対する森林蒸発散の持続性}

ここでは，IIIの 4 で示した図－7，8において，年 損失量が年末の基底流出量の変動と正の相関を持つ 傾向が森林の期間に明確で, 森林が回復していない 期間に不明確になる点について考察しょう。図一5 を用いて説明したように，正の2では，降水量の小 さい年に蒸発散量が貯留量の減少分を使って維持さ れるため, 損失量がその分だけ小さくなること, 引
き続く降水量の大きい年に貯留量が回復してその分 だけ損失量が大きくなることを述べた。これらのこ とが, 図一5，6において，損失量変動が年末基底 流出量変化に対して明確な相関関係を持つことにな る原因とみられる。また，水収支を表す（2）式か ら, 損失量は蒸発散量と貯留変動量の合計になるの で, 降水量の大きい年には森林の場合, 遮断蒸発量 が大きくなって（近藤ら，1992）蒸発散量全体が大 きくなるかもしれない。そうすれば，仮に貯留量が 大きくならなくても損失量は大きくなる，結局，森 林の蒸発散量が少雨年にもあまり抑制されず貯留量 が減少すること, 多雨年に遮断蒸発量が増加するこ と, 少雨年に引き続く多雨年では貯留量回復がある ことなどが合わさって, 年損失量と貯留量の間の強 い正の相関を産み出しているのであろう.

これに対して，森林が回復していない場合，少雨 年には蒸発散量も減少することになり, 貯留量減少 をともなわずにそれと独立に損失量が小さくなる。 そのため, 引き続く多雨年に貯留量減少を回復する ような因果関係が生じない。また, 樹冠が未発達で 遮断蒸発量が小さいため, 多雨年に蒸発散量が大き くならず，損失量も大きくならない，すなわち，損 失量が森林期間に比べて絶対量が小さく, 蒸発散量 減少による損失量減少はあるにしても, 損失量の変 動が貯留量変動に依存しにくい。ただし，年末の基 底流出量の変動は図一7，8に見るように必ずしも 小さくはない。これについては, 蒸発散量が貯留量 を大きく変動させる要因になる森林とは違って, む しろ他の要因がかかわっているのではないだろう か. 例えば且の2において北谷の1942年の水収支に 関して述べたように，年末に近い時期に降水がある かどうかなどの, 貯留量を流出量から推定する上で の誤差によって年末の基底流出量が変動しているの ではないかと考えられる。

以上の考察結果は，年末流出量の増減が損失量と 正の相関があること自体を問題にするものではな く, 森林の蒸発散が流域貯留量変動を大きく変動さ せることによって少雨年にも大きな值を維持してい る点の重要性を示すものである. 夕イの丘陵常緑林 に扔いては，3４月の乾季後半の最も土壤の乾燥す る季節に蒸発散量が大きくなることがわかっており (Tanaka et al., 2003)，それは根を4〜 $5 \mathrm{~m}$ 程度の深く に伸ばしていることでまかなわれると見積もられて いる（Tanaka et al., 2004)。また，シベリアのカラ マツ林では, 少雨年に拈いては, 前年に降って冬季 
に凍結保存された雨水を蒸散させることが明らかに なっており，多雨年・少雨年に限らずほぼ一定の蒸 発散量が維持されることが明らかにされている (Ohta et al., 2008).これらのことから, 長期の個体 生命を持つ樹木は, 一生の間に何度も訪れる厳しい 乾燥期間にも枯死することがないよう根を深く伸ば していて, 少雨期間も光合成と蒸散を維持しょうと する性質を持つとみられる。竜ノ口山の流域が森林 に被覆された期間において, 年単位の損失量と年末 基底流出量の増減に相関関係が生じたことは，こう した少雨年にも蒸発散を維持しょうとする森林固有 の性質が現れたためだということができよう.一方, 森林被覆が失われたり, 疎らだった期間においては, 流域貯留量の変動をもたらすような蒸発散は生じに くかったと考えることができる.

\section{3. マツと広葉樹の蒸発散特性の比較}

北谷の水収支期間に扔ける年蒸発散量の年平均気 温に対する関係を示した図一6には，南谷の期間平 均年損失量を併せてプロットしている. 表一4に示 されているように, 水収支期間の最初と最後におけ る南谷の年末基底流出量の值は北谷とは違って必ず しも一致しない. 北谷に比べて短期的な植生変化が 生じてきた南谷では, その変化が水収支に影響しゃ すいためと推定される。 そこで, 年末基底流出量に 差があって平均年損失量と平均年蒸発散量が一致す るとの前提が必ずしも満足されないが, 南谷のクロ マツ幼齢林であった期間とマツ枯れ後の広葉樹林期 間の損失量の違いはほぼ蒸発散量の違いによるとみ て比較することにした。 以下では, 厳密には期間平 均の年損失量ではあるが, 年蒸発散量と呼ぶことに する．表一4と図一6の右図には, クロマツ幼齢林 であった期間1969〜 79年 (B’) と広葉樹の期間 (E)の 北谷と南谷の年蒸発散量を示している. B' とE両期 間の南谷の蒸発散量を比較すると, それぞれ $861 \mathrm{~mm}$, $884 \mathrm{~mm}$ で, 広葉樹林の期間がクロマツ幼齢林の期 間よりも $17 \mathrm{~mm}$ 大きい. しかし, 北谷を基準にする と, $\mathrm{B}$ '期間の南谷の蒸発散量は北谷よりも $70 \mathrm{~mm}$ 大 きいことになる。一方, 南谷が広葉樹林であった $\mathrm{E}$ 期間は北谷よりも $12 \mathrm{~mm}$ 大きい。そこで, 北谷を基 準とすれば，南谷におけるクロマツ幼齢林の期間の 蒸発散量は, 広葉樹の期間に比べ, 南谷だけでの比 較結果とは反対に, $70 \mathrm{~mm}$ と $12 \mathrm{~mm}$ の差である $58 \mathrm{~mm}$ 程度大きいとみるのが妥当と結論づけられる。

これに対して他の期間, 南谷が筋刈後に山火事が
発生してその後のクロマツ再生が進んでいないAの 期間，クロマツ枯損の影響があったCと Dの期間は, 南谷の損失量が北谷よりも小さいので，その期間の 南谷の年平均蒸発散量は, クロマツ幼齢林のB' 期間 よりも小さく, 広葉樹林のE期間よりも小さいとい う判断が可能である。こうした結果はすでに得られ ていた傾向（藤枝·阿部, 1982 ; 阿部・谷, 1985) と同じであって, ここでは, 北谷蒸発散量の長期変 化を考慮した上でその傾向を確認できたということ になろう。

さて, 南谷がマツ林であったB' 期間と広葉樹林 であったE期間については, 前者の年蒸発散量が大き いと結論づけたが, さらに, 季節毎の蒸発散の構成 成分に関して, 月流出量の比較から考察を加えよう.

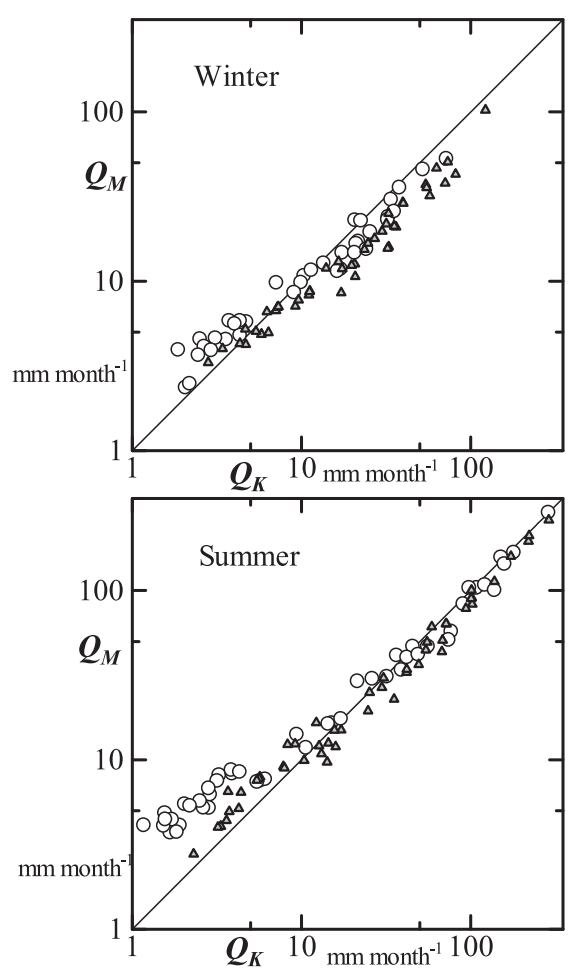

図－9 南谷がクロマツ幼齢林の場合 $(\boldsymbol{\Delta}:$ : 1969〜 79年, 表－4のB' 期間) と広葉樹林の場合 $(\bigcirc: 1992$ 2001 年, E期間) における月流出量の北谷 $\left(Q_{K}\right)$ と 南谷 $\left(Q_{M}\right)$ の比較

上は冬季 $(1 \sim 4$ 月), 下は夏季 $(6 \sim 10$ 月).

Fig. 9 Comparison of monthly runoff totals between Kitatani $\left(Q_{K}\right)$ and Minami-tani $\left(Q_{M}\right)$ when Minami-tani was covered with a young stand of black pine trees (A, 1969-1979) and when it was with a broad-leaved forest $(\bigcirc$, 1992-2001).

Upper, winter (January-April); Lower, summer (JuneOctober). 
図一9は，B’期間とE期間における月流出量の北谷と 南谷の関係を，冬季（1４月）と夏季（6〜10月）に 分けて図示したものである.なお，表一3に示した欠 測を含む月はすべて除いた。北谷と南谷では，どち らも広葉樹であるE期間では, 流出量の小さい月には 後者の月流出量が大きく, 流出量の大きい月にはほ ぼ同じかまたは前者の月流出量が大きい傾向がある. これは，IVの1にも記したように石英斑岩の比率が南 谷より北谷に大きく, 北谷の斜面勾配が急で土壤が うすいことが原因であり, 地中の流出機構の差から 説明できる，つまり，地上植生が仮に同じであって も, 北谷は南谷よりも洪水流出への降雨配分が大き く, 降雨終了後の基底流出と蒸散・地表面蒸発を生 じさせる土壤貯留への降雨配分が小さい. そのため, 降雨量が大きく洪水流出量が大きい月には, 北谷の 流出量が大きく, 降雨量が少なく洪水流出量が小さ い月には，南谷の流出量が大きくなりやすいことに なる.このE期間では, 表一4から南谷の蒸発散量が $12 \mathrm{~mm}$ 大きいので, 月流出量の小さいときに南谷の 流出量が北谷よりも大きい傾向は, 水収支式から単 純に推定されるのとは逆になる。したがって, 地中 の降雨配分を決める流出機構がかかわっていなければ 説明できないことである.

このような北谷と南谷の流出機構の差をふまえた うえで, 南谷の植生がマツ林であったB'期間と広 葉樹林であったE期間を比較する。図一9に扔いて, 月流出量の小さい範囲でマツ林の期間の流出量が広 葉樹の期間よりも小さい傾向は, 冬よりも夏に明膫 である。また，月流出量の大きい範囲では，夏は， マッ林と広葉樹の期間のプロットは混じり合うのに かかわらず，冬は，マツ林期間が広葉樹期間よりも 明確に小さい。図一9は対数表示で描かれているの で, 冬は, 2期間の流出量差の絶対量は降雨量の大 きいときに大きくなっている。こうした冬の流出量 差の傾向は, 遮断蒸発量の性質, すなわち, 蒸散と は異なり夏冬の季節変化がそしく（Suzuki，1980）， むしろ降雨量の大きいときに大きくなること（近藤 ら，1992）から説明されるべきこととみられる。一 方, 夏は, 流出量の大きい月に拈いて, 月流出量の マツ林と広葉樹林の差が冬より小さいことは, マッ 林の遮断蒸発量が広葉樹林よりも大きい程度が冬よ りも夏で小さいからだと推定される. 夏のプロット が混じり合う結果は, 遮断蒸発量の差が冬と同じで あってもマツ林の蒸散量が広葉樹林よりも小さけれ ば起こり得るかもしれないが，もしそうであれば，
降雨量が小さい夏の期間に，マツ林の流出量が広葉 樹林よりも明瞭に小さい傾向を説明することができ ない. 夏には, マツ林と広葉樹林の遮断蒸発量の差 は冬よりも小さく, 林床に落ちて土壤でいったん貯 留される水量は両者でそれほど異ならないが，マッ 林の蒸散量が大きいために, 基底流出量のウェート が大きい月流出量の小さい月に，マツ林の月流出量 が広葉樹林よりも小さくなったと推定するのが妥当 と考えられる.

以上のように，1969-79年のクロマツ幼齢樹林は， 1992-2001年の常緑樹を高木層とする広葉樹林に比 べて, 冬の遮断蒸発量が大きく, 夏の蒸散量が大き いために，一年中にわたって月流出量を小さくする 結果になったと推定できる。落葉広葉樹林よりもマ ツ林の蒸発散量がかなり大きい傾向は, アメリカで 基準流域法によって明らかにされている（Swank and Douglass, 1974)。しかるに, Komatsu et al. (2007) や小松ら（2007）は，降水が夏に少なく冬に多いア メリカでは, 常緑林であるマッと落葉広葉樹とでの 遮断蒸発量の差が大きく現れるのに対して, 夏に多 雨の日本の無雪地域では, 遮断蒸発の差が現れにく いとしている。そして, 竜ノ口山南谷のマツ林の時 期と広葉樹の時期における年蒸発散量の差がほとん どないことを例に挙げている. しかしなから, 本論 文は, 北谷の蒸発散量の違いを基準として, 同じ データからマツ林の蒸発散量が大きいと結論づけ た. 冬季の降水量がアメリカで大きく, 日本の太平 洋側で小さいことは, 確かに常緑樹の遮断蒸発量が 前者で大きいことを説明する要因ではあるが，マッ の早生樹種としての特徵も考えなければならない. Komatsu et al. (2007) は, マッとスギ・ヒノキとを ひとくくりにして針葉樹として扱い, 広葉樹と比較 している. しかしながら, 岡山県のやせ地での調査 によれば, マッの成長速度はスギ・ヒノキよりも大 きいことがわかっている(山本，1986）。したがっ て, マッの蒸発散量はスギ・ヒノキよりも大きいと 考えられる。体の太平洋側の気候条件で, 冬の遮 断蒸発量と夏の蒸散量がともにマツ林が広葉樹林よ り大きいことに基づいて, マツ林の年蒸発散量が広 葉樹林に比べて大きくなるという本論文の解析結果 は，一般性を持つ妥当なものといえよう。

\section{4. 年蒸発散量に及ぼす個別要因の影響分離の試み}

竜ノ口山の北谷と南谷の69年間にわたるデータか ら, 年蒸発散量に及ぼす気象条件と植生条件の変動 
影響について検討してきた。しかし，両方の変動要 因を分離して評価することはそう簡単ではないとい う点を指摘しなければならない。気候条件の長期変 動は, 図一3に示すように, 都市化の違いを除けば, 比較的広域で同じような変化がみられるようであ る。しかし，短期間に変化を見出し得る森林伐採や 自然枯損とは違い，成長による蒸発散量の長期変化 は，気候変動と絡み合って現れる。気候変動が植生 成長を変化させて間接的に蒸発散量に影響すること もあるので，分離評価が難しい。こうした植生変化 と気候変動の影響の重なり合いを分離する研究テー マにおいては，これまで，長期間植生が自然の成長 に任せられた北谷が解析対象として重要と考えてき た。すなわち，図一6に表したような，ある程度森 林が回復してきた1959年以降の北谷の蒸発散量に及 ぼす気温変化の影響を中心に議論してきたのであ る。しかし，考察の最後の節に抒いては，上記の 「植生変化と気候変動の影響の分離」というテーマ にもう一度立ち返り，図一4に示された北谷・南谷 の全期間にわたる年損失量の年々変動に着目して, 観測全期間にわたって, 気候変化と植生変化の両要 因の影響について総合的な考察を加える.

まず，観測当初のアカマツ林の時期における損失 量変動については, 図一5に詳しく示したところで あるが，南谷の損失量 $860 \mathrm{~mm}$ (1937-43平均) は北 谷の $841 \mathrm{~mm}$ よも $19 \mathrm{~mm}$ 大きく, 年々変動はほぼ 平行に推移している。しかし, 極端な乾燥年には, 南谷 $570 \mathrm{~mm}$ ，北谷 $572 \mathrm{~mm}$ となって，わずかだが南 谷が小さい。土壤が厚い南谷の蒸散量が夏でも大き い傾向があると考えてきた（IVの3）が，こうした 極端な乾燥年には南谷の蒸発散抑制が北谷と同レベ ルで生じていたのかもしれない.図ー4 (B)の偏差 積算曲線の折れ点からマツ枯損の水文学的影響は 1943年に起こったとみられるが，1939年と翌1940年 の少雨による水ストレスが枯損とかかわっていると 推測される１980年における南谷のクロマツ枯損の 際も，それに先立つ1977，1978 年の小さい降水量 $1,100 \mathrm{~mm}, 820 \mathrm{~mm}$ がそれに関係するとみられるの である。森林では深く根を伸ばすことにより夏の大 きな蒸散量が維持され，抑制が少ないとの傾向をこ れまで指摘してきたが，それには限界があることを 示唆している，乾燥がどこまで進んでも維持される とは必ずしも言えない閾值の存在 (Zehe and Sivapalan, 2009）を考えておかなければならない.

次に, 1947年以降放置された当時について見ると,
北谷では，1957年までと1958年以後で損失量の傾向 が異なる．1958年までは竜ノ口山の気温データがな いので，津山の年平均気温を参照し，図一4(C) の 津山の気温変化を見ると，1944～58 年の 15 年（年平 均で $\left.13.2{ }^{\circ} \mathrm{C}\right)$ は $1961 \sim 70$ 年 (平均で $13.2{ }^{\circ} \mathrm{C}$ ) と比べ て低温ではない。したがって，1958年までの15年 の損失量（平均で743 $\mathrm{mm}$ ) が1961〜 70年（平均で $798 \mathrm{~mm}$ ）よりも少ない原因は, 気温によるもので はなく，マツ伐採後森林が回復していないためと確 認できる。一方, 南谷はマツ枯損後の損失量の変化 が北谷とは違っている，立ち枯れ状態のマツが残さ れていた1944年から1947年までは, 南谷の損失量は 北谷と同じような変化であるが，伐採終了後の1948 年からは, 北谷は相変わらず，平均よりも小さい損 失量であるのに, 南谷の損失量は平均的な值に増加 して，両者が大きく異なっている。ササ類の繁茂が 北谷に乏しく南谷に著しかったことがかかわってい るのだろう。図一7，8を参照すると，1944～57年 の損失量と年始年末の基底流出量の差との相関関係 は，北谷ではまったくないようだが，南谷では弱い 傾向は認められる。しかし，南谷でも，この期間は， 森林でお扔われていた1937〜 43年，1968～79年， 1995２005年の期間に見られる強い相関はない。こ のような結果は，図一4(A)（D）を見てわかるよう に，この期間には降水量が特に小さい年がなかった ため，南谷では，森林未回復で根の浅いササ類が繁 茂する状況においてさえ, 蒸散抑制が起こるような 乾燥状態に至らなかったと推測される。これに対し て, 北谷では土壌がうすいために，南谷に比べて貧 弱なササや土壤表面からの蒸発散量が小さくなった ため，蒸散抑制が毎年生じて年蒸発散量が恒に小さ く, 蒸発散量が貯留量変動に影響を及ぼさなかった のだろう。その後, 1954〜 56年のヒノキ植栽後には, 南谷の損失量が減少して北谷と近くなっている (1955～58年)。これは，筋刈などもあって，ササに よって支えられていた南谷の蒸発散量が小さくな り，北谷と同じように毎年の夏に蒸発散量が抑制さ れるようになったということであろう。

表一4, 図一6に示された北谷の1959年以降の蒸 発散量は，森林成長とは逆にA期間がB期間よりも 大きくなっており，気温による依存性がみられた。 図一4(B) の損失量の長期変化においてもこの傾向 がみられ，1959～61年の高温期以後 66年頃までと比 べて1970年の低温期には成長してゆく傾向に反して 損失量が小さくなっている，ところが，1987年以降 
は，損失量は確実に大きくなっている１989～93年 が多雨，1994年以降少雨であるが，こうした乾湿条 件を超えた明確な傾向が現れたとみられる。南谷は, 図－4(B) に見るとおり，1959年の山火事以降，北 谷に比べて損失量が平均よりも小さくなったが，ク ロマツ成長によって1968年以降は大きくなった。そ れが北谷よりも年平均で $70 \mathrm{~mm}$ も大き南谷のクロ マツ林の蒸発散量の特徵によるものであることは, すでにIVの3で述べたところである．1980年のマッ 枯損後, 再び損失量が平均より小さくなったが, 1986年からは平均的，1995年以降は北谷よりもわず かに大きい值で並行に推移し, 平均よりも大きな值 に転じている．北谷・南谷ともに，1987年頃からの 温暖化による蒸発散量増加が見られるが，これはな ぜかについては現時点で答えられない，IVの1に書 いたとおり，説明すべき大きな研究テーマと言うこ とになる。

ここで興味深いことは, 森林成長による蒸発散の 増加は, 気温を中心とした気象要因への依存を考え たうえで見直しても，急に変化する傾向がみられる ことである。北谷では, 1947年のマツ伐採後12年経 過した1959年に, 南谷では, 1959年の山火事後9年 経過した1968年に，また，1980年のマツ枯損後6年 経過した1986年と15年経過した1995年に転換点があ る。とりわけ，1986年以降の高温期にみられる1995 年の転換点は, 北谷にはみられず気象要因に依存し たものではない．南谷において樹冠上層を占めてい たクロマツの枯損後に常緑広葉樹を主体とした混交 林が成長したことに伴う蒸発散量独自の増加を示唆 している，Iでも指摘したように，森林伐採後に森 林が再生して $10 \sim 15$ 年程度で蒸発散量が回復する傾 向は，森林伐採の流出影響試験において広く見られ るものである（野口・藤枝, 2007)。扔そらく, 樹 冠閉鎖が完成することによるとみられるが，マツ枯 損後の2段階の変化を含め, こうした急な変化の理 由については，ここでは推定以上の見解は提示でき ない.これも今後の課題である.

\section{V。扔わりに}

本論文では, 植生が放置された流域と, 頻繁に変 化した隣接流域の水文デー夕を基にして, 年蒸発散 量の長期変化について解析した。できるだけ個別要 因の影響を区別してまとめれば，次のようになるだ ろう。
毎年の水収支においては貯留量変動が大きく, 蒸 発散量を損失量から区別して推定することは難しい が, 貯留量変動は年始年末の基底流出量の変動に よって指標とすることができる。

年平均気温を代表とする気象要因によって蒸発散 量は変化するが, 森林の場合は少雨年でも抑制されに 〈, 貯留量の減少によって蒸発散がまかなわれる, そ の貯留量減少は, 引き続く多雨年に増加回復する.

森林が失われたときには蒸発散量が小さくなり, 少雨年に蒸発散量が貯留量減少によってまかなわれ る傾向はほとんど見られなくなる.

植生が失われて森林が回復する過程では, 蒸発散 量が徐々に増加していくのではなく, 数年から 15 年 程度経過した頃に気象条件とは独立に大きな值に变 化する傾向がある。

早生樹であるマツの森林は広葉樹混交林に比べ て, 冬の遮断蒸発量と夏の蒸散量がともに大きい. こうした植生条件の影響は, 気象条件の影響との重 なり合いを除去して初めて十分に理解できる.

温暖化による蒸発散量増加は1987年頃から現れ, 1995年頃から北谷・南谷共通に顕著となっている. 気温上昇に対する増加割合から見ても大きな蒸発散 量増加であり, これについてのプロセス理解は今後 の課題になる.

以上の中で, 森林が少雨年に打いても蒸散量を維 持する傾向が強いことは，特筆すべき結果である. 塚本（1998）は, 緑のダム機能の他に緑のポンプ機 能について言及しているが, 本論文の結論は, 森林 の蒸発散が水ストレスに抗して示す強い持続性を明 らかにし, ポンプ機能を裏付けるものだからである. 最近では, 海岸から千キロ以上遠い南米アマゾンや シベリアに見られる大陸奥地の森林を維持する湿潤 気候は, 大気へ水を安定的に供給する森林蒸発散に よる緑のポンプ機能で支えられていると推定されて いる (Makarieva and Gorshkov, 2007). しかしなが ら，日本列島のような海洋に囲まれた島嶼において は, 蒸発散の降水へのフィードバックではなく, ア ジアモンスーンによる海洋からの水蒸気流入によっ て湿潤気候がもたらされる。その水循環環境では, しばしば出現する少雨年の水資源確保のためには, 緑のポンプの機能を抑制することが必要である。そ れには森林伐採が効果的であり, 本論文での考察か ら, その効果は植栽後 10 年程度の幼齢林の期間は確 実に持続するといえる。竜ノ口山での水文試験のき っかけとなった平田・山本論争の当事者である山本 
（1919）は，農民の水利用実態を詳細に分析した上 で，「森林の水分消費量を減少せしむる林業的手段」 として全山が壮齢期に達さないように法正林施業を 行うべきだと述べている。100年近くも経過した今, 論争の対象とされたまさにその場所において, その 主張が実証されたと考えられる。

他方, 洪水緩和の観点から論じた別稿 (Tani et al., 2011 ; 谷, 2011）では，それに対する土潩保全 の重要性を強調している。 その面から大面積皆伐は 望ましくない.したがって, 緑のポンプと緑のダム の両機能の知見を総合して, 気候条件や流域条件に 応じて森林管理法を選ぶことが必要ということにな る.また, 竜ノ口山北谷の植生はコナラであるが, いかに森林といえども, 温暖化に沿って限度なく蒸 発散量を増加させてゆくことはできない（Jung et $a l ., 2010) .1939$ 年のような $600 \mathrm{~mm}$ 程度の極端な少 雨に対しては森林衰退の可能性が危惧される。現実 的には，より早く，カシノナガキクイムシによる被 害も予想される．的確な森林施業を選択するために は, 緑のダムとポンプへの洞察はもちろん, 気候変 動に対する生態系応答を重視する必要性も高まって きたと言わなければならない.

\section{謝辞}

森林総合研究所の理水試験地データベースとして 公開された, 竜ノ口山森林理水試験地のデー夕のお かげで，本稿の解析は実施することができた。同研 究所の坪山良夫氏, 玉井幸治氏, 後藤義明氏, 阿部 敏夫氏, 小林忠一氏, 島村秀子氏を初めとする諸氏 に謝意を表す。また, 東北大学名誉教授の近藤純正 氏のホームページを利用させて頂き，気温の長期変 化について学ぶことが多かった，さらに，編集委員 として査読にかかわられた海洋研究開発機構・地球 環境変動領域の田中克典氏や匿名の查読者からは, 複雑になりがちな論旨に対して適切丁寧な指摘をい ただいた。京都大学農学研究科の小杉緑子氏から気 温と蒸発散の関係について助言をいただき，滋賀県 森林センターの小島永裕氏から森林と水に関する行 政について示唆をいただいた。これらの方々に感謝 したい。グローバルCOEプログラム「生存基盤持続 型の発展を目指す地域研究拠点」(代表: 杉原薰京 都大学東南アジア研究所教授), 三井物産環境基金 「森林の水循環に抒ける諸機能を流域管理計画に導 入する戦略に関する研究」(代表：谷）の支援を受 けたことを感謝とともに記す。

\section{引用文献}

阿部敏夫・谷 誠1985. 松くい虫による松枯れが流出に及ぼす影響. 日本林学会誌 $67: .261-270$.

愛知演習林1981. 愛知演習林量水観測結果報告 (III). 演習林22: 84-191.

愛知演習林1984. 愛知演習林量水観測結果報告 (IV). 演習林 23 : 57-88.

愛知演習林1987. 愛知演習林量水観測結果報告 $(\mathrm{V})$. 演習林 25 : 135-151.

愛知演習林1999. 愛知演習林量水観測結果報告 $(\mathrm{VI})$. 演習林 38 : 127-146.

愛知演習林・演習林研究部1976. 愛知演習林量水観測結果報告 (I). 演習林 $20: 39-64$.

愛知演習林・演習林研究部1977. 愛知演習林量水観測結果報告 (II). 演習林 $21: 48-89$.

浅野友子. 芝野博文. 蔵治光一郎2005. 東京大学愛知演習林白坂 流域における70年間の水収支観測結果. 日本森林学会大会講 演要旨集 $116: 463$.

防災研究室・岡山試験地1981. 竜の口山量水試験地報告. 林業試 験場関西支場年報22:56-69.

Bosch JM, Hewlett JD 1982. A review of catchment experiments to determine the effect of vegetation changes on water yield and evapotranspiration. Journal of Hydrology 55: 3-23, doi:10.1016/0022-1694 (82) 90117-2.

千葉徳爾1973. はげ山の文化. 学生社; 233.

Ding YJ, Ye BS, Han TD, Shen YP, Liu SY. 2007. Regional difference of annual precipitation and discharge variation over west China during the last 50 years. Science in China Series D: Earth Sciences 50: 936-945, DOI: 10.1007/s11430007-0042-8.

Farley KA, Jobbágy EG, Jackson RB. 2005. Effects of afforestation on water yield: a global synthesis with implications for policy. Global Change Biology 11: 1565-1576, DOI: 10.1111/j.13652486.2005.01011.x.

藤枝基久・阿部敏夫1982. 竜の口山試験地における森林の成立 が流出に及ぼす影響. 林業試験場研究報告317: 113-138.

福嶌義宏・鈴木雅一1986. 山地流域を対象とした水循環モデルの 提示と桐生流域の10年連続日 ・時間記録への適用. 京都大学演 習林報告57:62-185.

後藤義明 - 玉井幸治 - 小南裕志 - 深山貴文2005. 竜の口山森林理 水試験地観測報告 (1981年1月～2000年12月). 森林総合研究 所研究報告394:87-133.

後藤義明・玉井幸治・深山貴文・小南裕志 - 細田育広2006. 竜の 口山森林理水試験地における広葉樹二次林の階層構造に及ぼ す攪乱の影響. 森林総合研究所報告400:215-225.

IPCC 2007. “IPCC第4次評価報告書統合報告書政策決定者向け要 約”, 環境省, 2009/3/23, http://www.env.go.jp/earth/ipcc/4th/ syr_spm.pdf. (参照：2011/08/02).

Irmak S, Payero JO, Martin DL, Irmak A, Howell TA. 2006. Sensitivity analyses and sensitivity coefficients of standardized daily ASCE-Penman-Monteith equation. Journal of Irrigation and Drainage Engineering 132: 564-578, DOI: http://dx.doi.org/10.1061/(ASCE) 0733-9437 (2006)132:6 (564) .

Jung $M$, Reichstein $M$, Ciais $P$, Seneviratne SI, Sheffield J, Goulden ML, Bonan G, Cescatti A, Chen J, de Jeu R, Dolman AJ, Eugster W, Gerten D, Gianelle D, Gobron N, Heinke J, Kimball J, Law BE, Montagnani L, Mu Q, Mueller B, 
Oleson K, Papale D, Richardson AD, Roupsard O, Running S, Tomelleri E, Viovy N, Weber U, Williams C, Wood E, Zaehle1 S, Zhang K. 2010. Recent decline in the global land evapotranspiration trend due to limited moisture supply. Nature 467: 951-954, DOI:10.1038/nature09396.

関西支場防災研究室・岡山試験地1979. 竜の口山森林理水試験 地観測報告 (1959年1月～1977年12月). 林業試験場研究報告 308: 133-195.

気象庁 2011. “過去の気象データ検索”, 気象庁, http://www.data.jma.go.jp/obd/stats/etrn/index.php. (参照 : 2011/08/02).

Komatsu H, Tanaka N, Kume T. 2007. Do coniferous forests evaporate more water than broad-leaved forest in Japan? Journal of Hydrology 336: 361-375, DOI:10.1016/j.jhydrol.2007. 01.009.

小松 光・久米朋宣・大槻恭一2007. 流域水収支データの現代 的意義一森林蒸発散を考えるために一. 日本林学会誌 89 : 346-359.

近藤純正2009. “研究の指針 (K45. 気温観測の補正と正しい地球 温暖化量)”, 近藤純正, http://www.asahi-net.or.jp/ rk7jkndu/kenkyu/ke45.html. (参照: 2011/08/02).

近藤純正・中園 信・渡辺 力1992. 日本の水文気象 (2): 森林にお ける降雨の遮断蒸発量. 水文・水資源学会誌5 (2):29-36.

Kosugi Y, Katsuyama M. 2007. Evapotranspiration over a Japanese cypress forest. II. comparison of the eddy covariance and water budget methods. Journal of Hydrology 334: 305-311, doi:10.1016/j.jhydrol.2006.05.025.

Lozowski EP, Charlton RB, Nguyen CD, Wilson JD. 1989. The use of cumulative monthly temperature anomalies in the analysis of local interannual climate variability. Journal of Climate 2: 1059-1068, DOI:10.1175/1520-0442 (1989) 002<1059:TUOCMM> 2.0.CO;2

Makarieva AM, Gorshkov VG. 2007. Biotic pump of atmospheric moisture as driver of the hydrological cycle on land. Hydrology and Earth System Sciences 11: 1013-1033, DOI:10.5194/hess11-1013-2007.

三浦健志・諸泉利嗣2004. ペンマン蒸発散位に対する気象要素の 感度解析. 平成16年度農業土木学会全国大会講演要旨集：686687.

Monteith JL 1965. Evaporation and Environment. In The State and Movement of Water in Living Organisms, Fogg, GE (ed). 19th Symposium of the Society for Experimental Biology, Cambridge Press: Swansea, UK; 205-234.

中野秀章1976. 森林水文学, 共立出版; 228.

野口正二・藤枝基久2007. 森林流域試験と今後のあり方. 森林総 合研究所報告403:111-125.

農林省林業試験場1961. 森林理水試験地観測報告 (日降水量・日 流出量). 農林省林業試験場; 225.

太田猛彦・奥 敬一・小椋純一2009. 全国植樹祭60周年記念写 真集一かつて, 日本の山にはこんな姿もあった一. 国土緑化推 進機構; 51 .

Ohta T, Maximov TC, Dolman AJ, Nakai T, van der Molen MK, Kononov AV, Maximov T, Hiyama T, lijima Y, Moors EJ, Tanaka H. 2008. Interannual variation of water balance and summer evapotranspiration in an eastern Siberian larch forest over a 7year period (1998-2006). Agricultural and Forest Meteorology 140: 1941-1953, DOI:10.1016/j.agrformet.2008.04.012.

林業試験場関西支場 1960 1985. 林業試験場関西支場年報 No.1 (昭和34 年度) No.26 (昭和59 年度).

http://www.fsm.affrc.go.jp/Nenpou/. (参照 : 2011/08/02).
森林総合研究所 2010. “FFPRI FWDB”, 森林総合研究所, 2010/11/04, http://www2.ffpri.affrc.go.jp/labs/fwdb/main.htm. (参照：2011/08/02).

Suzuki M. 1980. Evapotranspiration from a small catchment in hilly mountains (I) seasonal variations in evapotranspiration, rainfall interception and transpiration. Journal of Japanese Forestry Society 62: 46-53.

鈴木雅一 1985. 短期水収支法による森林流域からの蒸発散量推 定. 日本林学会誌67:115-125.

Swank WT, Douglass JE. 1974. Streamflow greatly reduced by converting deciduous hardwood stands to pine. Science 185: 857-859, DOI: 10.1126/science.185.4154.857.

武田繁後1942. 龍ノ口山水源涵養試験第一回報告 (昭和12-14年 両谷比較観測成績). 農林省山林局; 215 .

Tamai K. 2010. Comparison of discharge duration curves from two adjacent forested catchments-effect of forest age and dominant tree species. Journal of Water Resource and Protection 2: 742-750, DOI: 10.4236/jwarp.2010.28086.

玉井幸治・後藤義明・小南裕志・深山貴文・細田育広2008. 竜ノ 口山森林理水試験地観測報告 (2001年1月～2005年12月). 森 林総合研究所研究報告408:125-138.

Tanaka K, Takizawa H, Tanaka N, Kosaka I, Yoshifuji N, Chatchai T, Sirithanya P, Suzuki M, Nipon T. 2003. Transpiration peak over a hill evergreen forest in northern Thailand in the late dry season: assessing the seasonal change in evapotranspiration using a multilayer model. Journal of Geophysical Research 108, DOI: 10.1029/2002JD003028.

Tanaka K, Takizawa H, Kume T, Xu J, Chatchai T, Suzuki M. 2004. Impact of rooting depth and soil hydraulic properties on the transpiration peak of an evergreen forest in northern Thailand in the late dry season. Journal of Geophysical Research 109. DOI:10.1029/2004JD004865.

田中延亮・蔵治光一郎2011. 森林からの蒸発散量と気温の長期変 動に関する予備的研究. 日本地球惑星連合2011年大会予稿： AHW027-03.

谷 誠2011: 山地流域における自然貯留の洪水緩和機能に関す る方法論的考察. 水利科学318:151-173.

谷 誠・阿部敏夫1987. 森林変化の流出に及ぼす影響の流出モ デルによる評価. 林業試験場研究報告342: 41-60.

Tani M, Fujimoto M, Katsuyama M, Kojima N, Hosoda I, Kosugi K, Kosugi Y, Nakamura S. 2011. Predicting the dependencies of rainfall-runoff responses on human forest disturbances with soil loss based on the runoff mechanisms in granitic and sedimentary-rock mountains. Hydrological Processes, DOI:10.1016/j.jhydrol.2008.07.023.

徳地直子. 白井伸章・ 上田実希 - 福島慶太郎2010. 里山の植生変 化と物質循環一竹林拡大に関する天王山における事例. 水利科 学54:90-103.

塚本良則1998. 森林・水・土の保全一湿潤変動帯の水文地形学一. 朝倉書店；138.

山本久仁雄 1986. やせ地に有用樹種を植えるー20年の成長記 録一. 林業試験場関西支場研究情報 $1: 2$.

山本徳三郎1919. 森林と水源. 大日本山林会; 143.

Zehe E, Sivapalan M. 2009: Threshold behaviour in hydrological systems as (human) geo-ecosystems: manifestations, controls, implications. Hydrology and Earth System Sciences 13. 12731297, DOI:10.5194/hess-13-1273-2009.

$$
\text { (受付：2011年3月24日, 受理：2011年12月6日) }
$$




\title{
Dependence of Annual Evapotranspiration on a Long Natural Growth of Forest and Vegetation Changes
}

\author{
Makoto TANI 1) Ikuhiro HOSODA 2) \\ 1) Graduate School of Agriculture, Kyoto University \\ (Kitashirakawa-oiwakecho, Sakyo, Kyoto 606-8502, Japan) \\ 2) Kansai Research Center, Forestry and Forest Products Research Institute \\ (68 Nagaikyutaroh, Momoyama, Fushimi, Kyoto, 612-0855, Japan)
}

A 69-year record (1937-2005) of the precipitation and runoff in two small catchments at Tatsunokuchi-yama, Japan was analyzed to evaluate annual evapotranspiration in conditions of natural forest growth without treatment or vegetation changes. Considering the storage increase and decrease of the water balance in each year, the mean annual loss in a period when the baseflow runoff rates at the beginning and the end were almost identical was regarded as the mean annual evapotranspiration. This value in the catchment, where a broad-leaved forest had grown naturally after 1947 , increased with annual air temperature and forest growth, although some additional unknown causes might have accelerated the increase in evapotranspiration for the recent years of 1991-2005. The increase or decrease of the annual loss in each year was correlated with the difference of the baseflow runoff rates between the beginning and the end for periods of forest, but no correlation was found for periods of poor vegetation. This result shows that a robust evapotranspiration rate from a forest continued using stored water, even in dry years. The annual evapotranspiration in one of our study catchments was less for a period of black pine forest than for that of broad-leaved forest, but comparisons of the annual evapotranspiration and the monthly runoff values with those of another standard catchment suggest an opposite result: greater annual evapotranspiration with greater wet-canopy evaporation in winter and greater transpiration in summer from the pine forest than from the broad-leaved forest.

Key words : annual water balance, climate change, evapotranspiration, forest hydrology, vegetation change 